\title{
COMPETENCE OF COORDINATION IN LOWER LIMBS OF CHILDREN AGED 3-6: CLUES FROM
}

\section{THEIR BACKWARD WALKING}

\author{
Jin ZHOU ${ }^{1,2}$, Haozhen WU1, Mingyu HU ${ }^{1}$, Wuyong CHEN ${ }^{1}$, Jianxin $\mathrm{WU}^{2}$, Bo XU1* \\ ${ }^{1}$ National Engineering Laboratory for Clean Technology of Leather Manufacture, Sichuan University; Chengdu 610065, P. R. China \\ ${ }^{2}$ Science Lab, Zhejiang Red Dragonfly Footwear Co., LTD., Zhejiang Province, Wenzhou 325100, P. R. China \\ Received: 29.11.2017 \\ Accepted: 22.05 .2018 \\ https://doi.org/10.24264/Ifj.18.2.2
}

COMPETENCE OF COORDINATION IN LOWER LIMBS OF CHILDREN AGED 3-6: CLUES FROM THEIR BACKWARD WALKING

ABSTRACT. Since current literature does not explain how children aged 3-6 reacted when the walking direction was reversed or what its mechanism is, the aim of this study was to understand the mechanism of their 'Neuro-musculo-skeletal' systems in the process of direction changes, as well as its coordination features. The kinematics of forward walking (FW) and backward walking (BW) of 96 subjects were measured by the Coda motion system and their Euler angles in lower limb joints were first collected. According to the coordination algorithm, the phase angle (PA) in the knee and ankle and the continuous relative phase angle (CRP) between the two joints were calculated; further the mean, standard deviation (SD) and range of data for variables of PA and CRP were contrasted between FW and BW. All the statistical models were executed under SPSS with a significance level of 0.05 and a confidence interval of $95 \%$. The results show that children in BW first had an unstable velocity in their ankles; further, PA in both their ankles and knees were distributed in a limited range. Meanwhile the key gait events were not obtained in BW in all age groups. A similar CRP was seen between FW and BW, but a significant difference existed between the two types of gait. The majority of the mean and range of PA and CRP were recorded with significant distinctions between FW and BW in each age group. Finally, significant gender differences existed in all variables of BW in each age group. Overall, although achieving the BW was easy for preschool toddlers (aged 3-6), but their coordination in lower-limb were still in developing and further fine tuning; moreover, their clues in backwarding also tell the detail of development in the 'Neuro-musculo-skeletal' system.

KEYWORDS: backward walking, lower limb coordination, continuous relative phase, phase angle, healthy children

\section{CAPACITATEA DE COORDONARE A MEMBRELOR INFERIOARE LA COPIII DE 3-6 ANI: INDICII DATE DE MERSUL ÎNAPOI}

REZUMAT. Deoarece literatura actuală nu explică modul în care copiii cu vârste cuprinse între 3 și 6 ani reacționează când se inversează direcția de mers sau care este mecanismul, scopul acestui studiu a fost de a înțelege mecanismul sistemelor neuro-musculo-scheletice ale acestora la schimbarea direcției, precum și caracteristicile de coordonare ale acestora. S-a măsurat cinematica mersului înainte și a mersului înapoi în cazul unui număr de 96 de subiecți utilizând sistemul Coda motion și colectând mai întâi unghiurile Euler ale articulațiilor membrelor inferioare. Conform algoritmului de coordonare, s-au calculat unghiul de fază (PA) la genunchi și gleznă și unghiul de fază relativă continuă (CRP) între cele două articulații; în continuare, s-au comparat abaterea standard medie (SD) și intervalul de date pentru variabilele PA și CRP între mersul înainte și mersul înapoi. Toate modelele statistice au fost executate cu programul SPSS cu un nivel de semnificație de 0,05 și un interval de încredere de $95 \%$. Rezultatele arată că la copiii care au mers înapoi s-a observat mai întâi o viteză instabilă la nivelul gleznelor; în plus, unghiurile de fază la glezne și genunchi au fost distribuite într-un interval limitat. În același timp, momentele cheie din timpul mersului nu au fost obținute în cazul mersului înapoi în toate grupele de vârstă. $O$ valoare similară a CRP a fost observată comparând mersul înainte și mersul înapoi, dar a existat o diferență semnificativă între cele două tipuri de mers. Majoritatea mediilor și intervalelor PA și CRP au fost înregistrate cu distincții semnificative între mersul înainte și mersul înapoi în fiecare grupă de vârstă. În cele din urmă, au existat diferențe semnificative de gen în toate variabilele mersului înapoi din fiecare grupă de vârstă. În ansamblu, deși realizarea mersului înapoi a fost ușoară pentru preșcolari (cu vârste cuprinse între 3 și 6 ani), coordonarea membrelor inferioare este încă în curs de dezvoltare și ajustare; în plus, indiciile date de mersul înapoi, dezvăluie, de asemenea, detalii ale dezvoltării sistemului neuro-musculo-scheletic. CUVINTE CHEIE: mers înapoi, coordonarea membrelor inferioare, fază relativă continuă, unghi de fază, copii sănătoși

LA CAPACITÉ DE COORDINATION DES MEMBRES INFÉRIEURS CHEZ LES ENFANTS DE 3-6 ANS: INDICES DE LEUR MARCHE ARRIÈRE RÉSUMÉ. Étant donné que la littérature actuelle n'explique pas comment les enfants âgés de 3 à 6 ans réagissent en inversant le sens de la marche ou quel est le mécanisme, le but de cette étude est de comprendre le mécanisme de leurs systèmes neuro-musculo-squelettiques dans le cas du changement de direction, ainsi que leurs caractéristiques de coordination. On a mesuré la cinématique de la marche avant et de la marche arrière pour un total de 96 sujets en utilisant le système Coda motion et premièrement on a recueilli les angles d'Euler des articulations des membres inférieurs. Selon l'algorithme de coordination, on a calculé l'angle de phase (PA) chez les genoux et les chevilles et l'angle de phase relative continue (CRP) entre les deux articulations; puis on a comparé l'écart-type moyen (ET) et la plage de données pour les variables PA et CRP entre la marche avant et la marche arrière. Tous les modèles statistiques ont été exécutés avec le programme SPSS avec un niveau de signification de 0,05 et un intervalle de confiance de $95 \%$. Les résultats montrent que chez les enfants qui ont marche arrière, une vélocité instable de la cheville a été observée premièrement; de plus, les angles des chevilles et des genoux étaient répartis dans une gamme limitée. Dans le même temps, les moments clés de la marche n'ont pas été obtenus pour toutes les groupes d'âge. Une valeur de CRP similaire a été observée en comparant la marche avant et la marche arrière, mais il y avait une différence significative entre les deux types de marche. La plupart des moyennes et intervalles PA et CRP ont été enregistrés avec des distinctions significatives entre la marche avant et la marche arrière dans chaque groupe d'âge. Enfin, il y avait des différences significatives entre les sexes dans toutes les variables de la marche arrière dans chaque groupe d'âge. Dans l'ensemble, bien que la réalisation de la marche arrière était facile pour les enfants d'âge préscolaire (âgés de 3 à 6 ans), la coordination est encore en cours de développement et d'ajustement ; en outre, les indices de la marche arrière révèlent également des détails du développement du système neuro-musculo-squelettique.

MOTS CLÉS : marche arrière, coordination des membres inférieurs, phase relative continue, angle de phase, enfants en bonne santé

* Correspondence to: Bo XU, National Engineering Laboratory for Clean Technology of Leather Manufacture, Sichuan University; Chengdu 610065, P. R. China; email: 228447319@qq.com 


\section{INTRODUCTION}

Regarding movement, walking is under the control and coordination of the 'Neuro-musculoskeletal' system, which varies at different development stages. There are two stages in a child's development: The first stage spans the first 5-6 months after a toddler starts to walk, leading to rapid changes in terms of kinematics and kinetics [1]. The second stage represents a further fine-tuning of the gait pattern, lasting until the age of 8. Ages 3-6 [2] were the critical ages for building a way of motion which would affect their gait and posture later in their life. Feet are the only parts of the human body which have contact with the ground, and they play a major role in accepting load while in the stance phase and then in transferring this load to other parts of the lower limbs; but how the 'Neuromusculo-skeletal' mechanism coordinates the motion of the lower limbs when the walking direction changes was still not clear $[3,4]$.

It was acknowledged that neural control of forward walking (FW) and backward walking (BW) might largely originate from the same basic neural circuitry [5] and BW often presents a contrary motion cycle from that of FW [6]. In terms of FW, Hallemans studied the gait pattern of young toddlers and suggested that, after one year of independent walking, children's gait pattern had transferred from a flat foot to a heel contact one [7]; similarly, further foot development was confirmed by Bosch et al. [8] In terms of BW, Meyns [5] wanted to explain to what extent development plays a role in the maturation of neural control of gait in different directions. They first measured and contrasted the kinematics of both lower and upper limbs between the FW and BW; they then concluded that upper and lower limb kinematics of FW correlated highly to reversed BW kinematics in children. Moreover, Ledebt [9] indicated that children initially fixed their arms in a high guard position (external rotation in the shoulder, flexed elbows and hands at shoulder height) which then gradually changed to a low guard position as age increased (arms extending along the body without actively swinging). Fritz [10] contrasted the FW and BW in the adult and elderly populations and then recommended that clinicians were encouraged to assess BW, particularly BW velocity, as part of mobility examinations to identify those individuals in the elderly population at risk of falling. In addition, in terms of dynamics for adults, Lee et al. [11] found that there are significant differences in the ankle, knee and hip moments between FW and BW. However, whether a toddler at the beginning of age 3 has already mastered motion control in varied directions and achieved a better coordination or not, or to what extent of development before age of 6 the toddler could freely deal with those tasks and challenges were not seen in current literature.

Therefore, the aim of this study was to quantify the competence of coordination in lower limbs of children aged 3-6 by contrasting their gait variances between forward and backward walking, so as to understand the mechanism of the 'Neuro-musculo-skeletal' system in the process of direction changes. According to literature, the following hypothesis was proposed: since after independent walking, young toddlers were more familiar with the varied gait environments; hence, similar coordination strategies in BW would be found for children aged 3-6 and their competences in backward walking have been well developed.

\section{METHOD}

\section{Subjects}

In total, 96 healthy children between the ages of 3 and 6 were recruited in this study. The criteria for inclusion is shown below: (1) a body mass index (BMI) consistent with the BMI standard for normal Chinese children [12]; (2) no foot deformities or injuries; (3) the ability to walk independently; (4) no abnormal gait patterns, such as a crouching gait or equinus. All the measurements were executed after the details of this study were introduced to children's parents and their formal approvals were obtained. Moreover, all the measurements and procedures were registered in the University Ethic Committee followed the principles of Helsinki Declaration. 


\section{Motion Capture of Children's Lower Limbs}

The Coda Motion System (Coda Motion cx1, Charnwood Dynamics Ltd., United Kingdom) was used in this study to obtain the spatiotemporal parameters of children's lower limbs in normal walking. Two collectors were aligned on the two sides of the six-meter-long walking track, facing at an angle of 120 degrees. Twenty key positions were first marked for both sides of lower limb according to the Human Analysis Protocol of system (Fig. 1). Then Euler angle $(\mathrm{EA})(\theta)$ and angular velocity $(\omega)$ in zxy coordination sequence were calculated for knee $(\theta(\mathrm{OAB}) / \omega(\mathrm{OAB}))$ and ankle $(\theta$ ( $\mathrm{ABD}) / \omega$

(ABD)) using the Odin software (V1.02, Charnwood Dynamics Ltd., United Kingdom).

All subjects were asked to change into tight clothes when they arrived; and then the same researcher set markers. A three to five minute warm-up period was provided for their familiarization. Warm-up was composed by motion of several squatting and walking in the track; all those efforts were to eliminate the

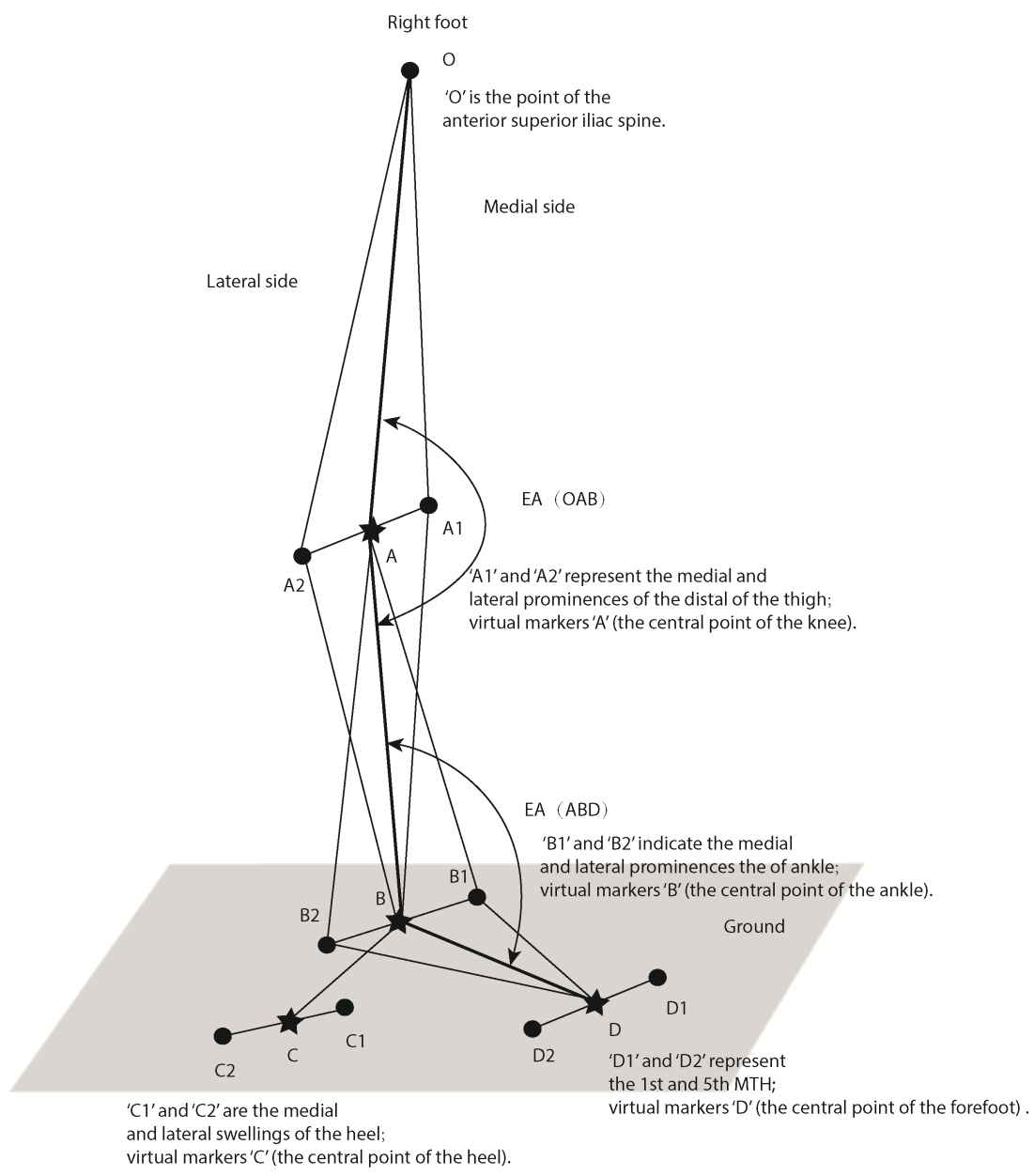

Figure 1. Markers in the lower limb

variance in measure. Afterwards, subjects walked at their own selected speed while the data was simultaneously recorded. At least five successful trials were required for each foot, where a success trail was defined as more than $90 \%$ data completion were achieved for all markers and at least two complete gait cycles were obtained.

\section{Data Processing}

According to the protocol developed by Clark [13], Miller [14] and Ross [15], phase angle (PA) of knee and ankle and continuous relative phase (CRP) between the knee and ankle $\left(\theta_{C R P}(K-A)\right)$ were chosen for further analysis 
and they were processed according to EQ 1-4. An

in-phase indicated that $\theta_{C R P}$ was within 0 and

30 degrees and the two joints rotated either clockwise or anti-clockwise simultaneously; while that of anti-phase was between 150 and 180 degrees and the two joints rotated in opposite directions [15]; other angles were classified as out-phase. Consistencies and coordinative stability in terms of PA and CRP were quantified by their mean values over the gait cycle, standard deviations (SD) and range of motion (ROM), which was defined as the difference between the maximum and minimum of the elevation angle trace [5].

$$
\bar{\theta}=2\left[\frac{\theta-\min (\theta)}{\max (\theta)-\min (\theta)}\right]-1
$$

$\bar{\omega}=\left[\frac{\omega}{\max (|\omega|)}\right]$

$$
\varphi(i)=\tan ^{-1}\left[\frac{\bar{\omega}(i)}{\bar{\theta}(i)}\right], i=1,2, \ldots, n
$$

$$
\theta_{C R P}(i)=\left|\varphi_{1}(i)-\varphi_{2}(i)\right|
$$

All the time series data were first filtered by a $6 \mathrm{~Hz}$ cut off and then the time period of a complete gait cycle was selected; further a quintuple spline procedure [16] was used to create a 100 point time-normalized gait cycle $(\mathrm{GC})$; then, time axis of backward walking were reversed and its gait cycle was modified as a reversed one (MGC).

\section{Statistical Analysis}

Intra-subject data was first averaged, and then inter-subject data. One sample K-S model was used to the test normal distribution, and all data were approved to be within normal distribution. However, distinctions existed between the left and right foot as examined by the independent $T$ test; thus, only the right foot was selected for further analysis. Variations between FW and BW in SD and ROM were explored by the Paired-t test; further, influences of gender was assessed by the ANOVA. All statistical models were executed under SPSS with a significance level of 0.05 and a confidence interval of $95 \%$.

\section{RESULTS}

The mean age is $4.6 \pm 1.1$ years, the mean body weight is $17.4 \pm 2.8 \mathrm{Kg}$, the mean height is $105.7 \pm 7.4 \mathrm{~cm}$ and the mean BMI is $15.6 \pm 0.5$. The details were shown in Table 1.

Table 1: Characteristics of all age groups children

\begin{tabular}{lllll}
\hline & Age 3 & Age 4 & Age 5 & Age 6 \\
\hline $\mathrm{N}$ & 27 & 34 & 28 & 7 \\
Gender (M/F) & $15 / 12$ & $16 / 18$ & $11 / 17$ & $4 / 3$ \\
Age (years) & $3.5 \pm 0.4$ & $4.4 \pm 0.3$ & $5.5 \pm 0.3$ & $6.0 \pm 0.0$ \\
Weight (kg) & $15.7 \pm 2.2$ & $17.3 \pm 1.7$ & $18.2 \pm 2.1$ & $22.2 \pm 3.1$ \\
Height (cm) & $99.3 \pm 5.5$ & $105.3 \pm 3.4$ & $110.0 \pm 4.3$ & $116.7 \pm 3.4$ \\
BMI & $15.8 \pm 1.3$ & $15.6 \pm 1.2$ & $15.0 \pm 1.1$ & $16.3 \pm 2.2$ \\
\hline
\end{tabular}


Relationship Between Euler Angles and Angular Velocities

In FW, the Euler angles and angular velocities of knees and ankles were distributed in a reasonable range. However, the ankle in
BW fluctuated unstable, with a particularly higher velocity in each age; additionally, with the exception of age 3 , knee control in BW was constrained within a specific range (Figure 2).
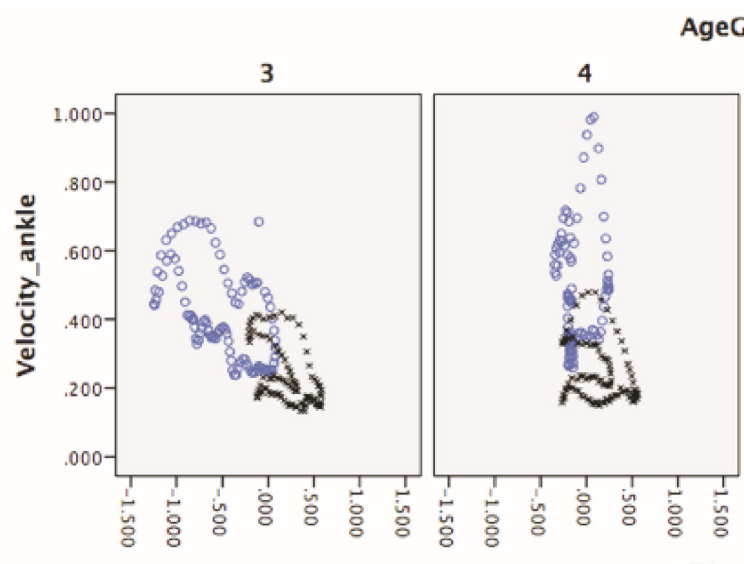

AgeGroup
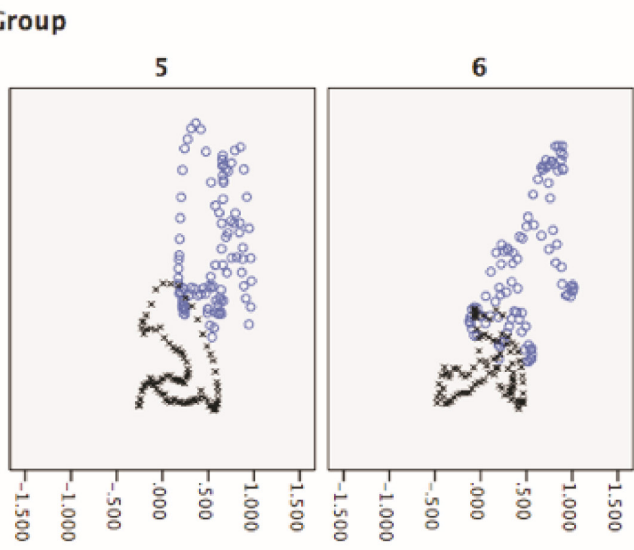

TypeSubjects $\circ \mathrm{BW}$
$\times \mathrm{FW}$
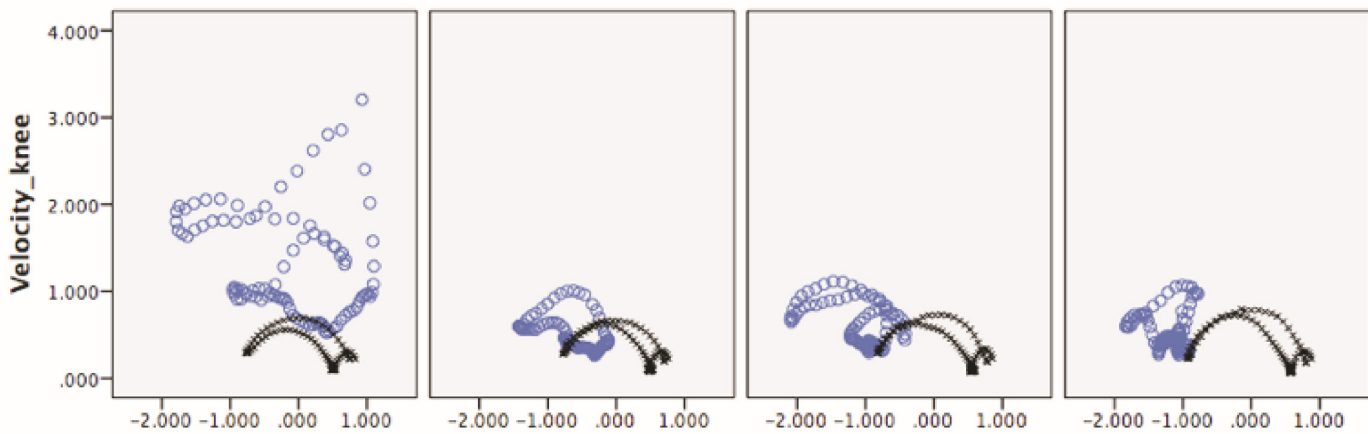

EA_knee

Figure 2. Scatter plot of Euler angle and angular velocity in ankle and knee

\section{Analysis of the Phase Angle and Relative Phase Angle}

Explicit knee and ankle movement in sequence with key gait events were seen in FW; further the knee was in extension at the beginning of the gait cycle. Before it kept this status in order to maintain stability in middle stance phase, it flexed in an initial heel contact to assist the cushion. Meanwhile, the ankle pivoted the body to move forward rapidly after touching the ground, and it shifted in the posture of dorsiflexion and plantarflexion. Whereas, FWBW variations existed in both PA and CRP (Fig. 3 ) and both knee and ankle were lack of key gait events while BW, where a limited motion was found as well; further both the PA of knee and ankle were distributed within a -25 to 25 relative angle, but their CRP was similar with that of the FW.

The distribution of PA and CRP could be further explained by SD and ROM. A limited ROM first found for the knee and ankle in each variable during the BW. Significant FW-BW differences in SD and ROM of PA were found for each age group ( $p=0.000$ for all) (Table 2 ), with the exception of the ROM of PA-Knee ( $P=0.45$ for $4 y, P=0.23$ for $5 y, P=0.17$ for $6 y)$. 

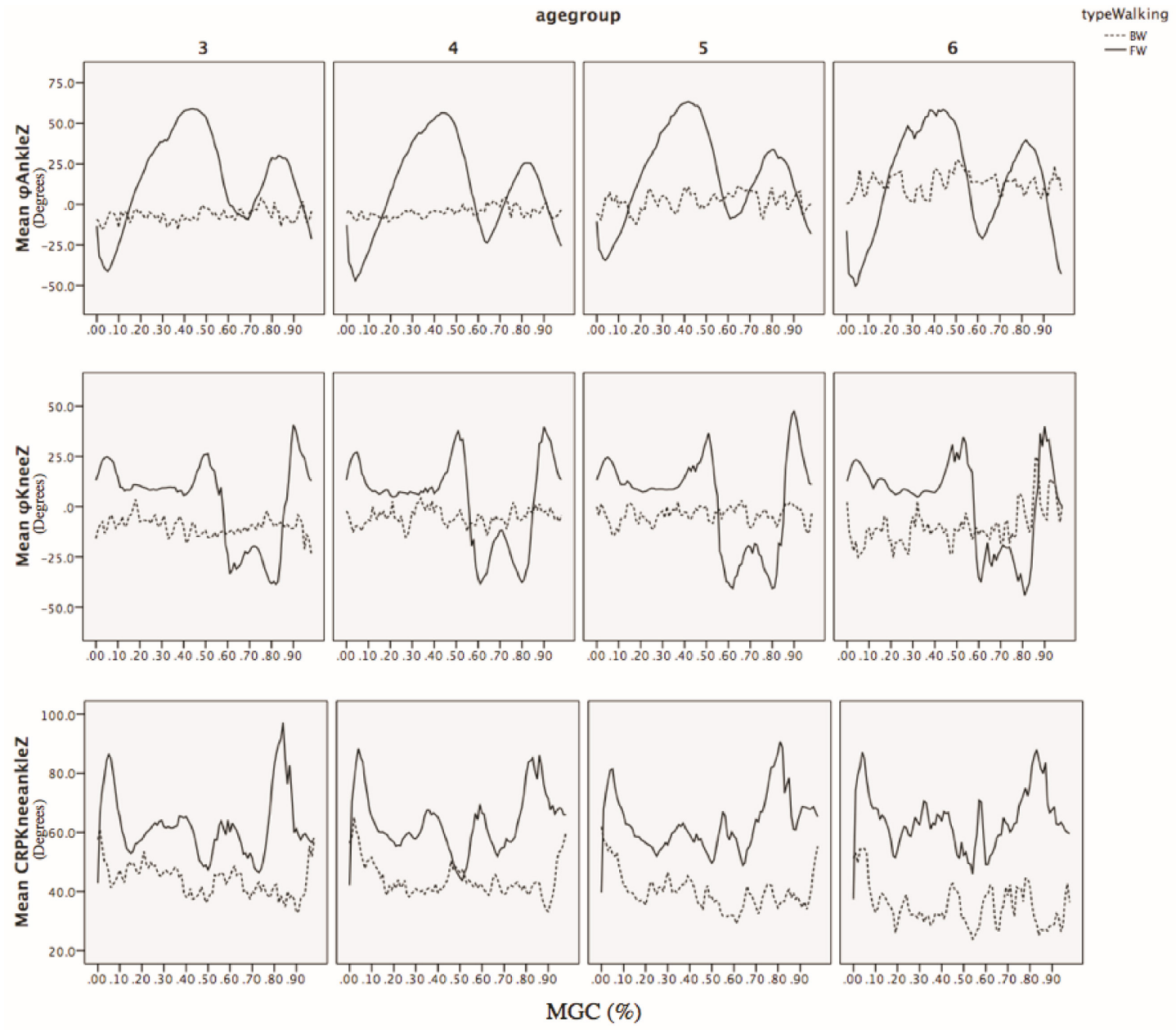

Figure 3. Distribution of the phase angle (PA) and relative phase angle (CRP) of the ankle joint and knee joint in the normalized gait cycle 


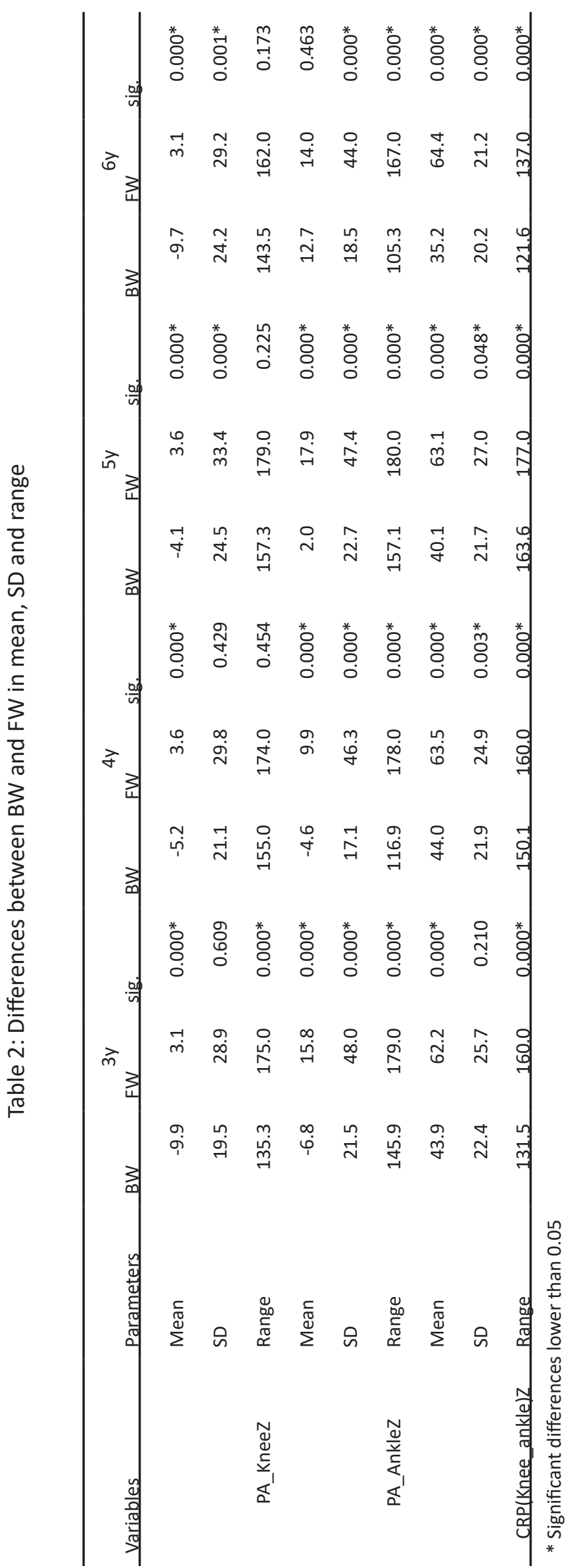

Revista de Pielarie Incaltaminte 18 (2018) 2 


\section{Analysis of Gender Differences}

Gender differences in FW were clear in references [17]. In terms of BW, girls age 3 were recorded with significant differences in their ankles compared with those of boys $(p=0.000$ for PA-ankle), where boys had limited motion in $15-55 \%$ MGC. Similar results were found in age 4 ( $P=0.000$ for PA-ankle). In 50-90\% MGC, significant differences in the PA of knees $(p=0.02)$ were found between boys and girls aged 5 and 6 recorded with a higher PA-Knee $(p=0.00)$ during the entire gait cycle. Finally, significant gender differences were found in age $3(p=0.000), 4$ $(p=0.008)$ and $6(p=0.001)$ in CRP variables.

\section{DISCUSSIONS}

In this study, 96 healthy children aged 3-6 performed forward and backward walking; the kinematic data were collected by a 3D motion system. According to an algorithm of the coordinates, PA and CRP in the knee and ankle were evaluated and further contrast between FW and BW was made. Our results show that children in BW had an unstable velocity in their ankles; further, the PA in both the ankle and knee had a limited range of distribution. Meanwhile, the key gait events were not shown in BW in all ages groups. Similarly, the CRP of BW was recorded as in FW, but with significant differences between the two types of gait. The majority of the mean and range of the PA and CRP were recorded with significant differences between FW and BW in each age group. Moreover, significant gender differences existed in all variables of each age group in BW.

Pieter [5] reported that most of the gait features in FW are confined in BW, and they also indicated that coordination stability of BW was slightly attenuated. Nevertheless, they summarized that the FW/BW differences were slight for schoolchildren. However, in our study, BW was shown to be quite different from FW for preschool children (aged 3-6). Firstly, a higher velocity of ankle rotation was obtained; this finding implied that although walking speed was lower in BW, which was similar with that of a blindfolded subject [18], the motion of the ankle seemly sped up, so as to adjust the ground touching with higher mobility. Secondly, we also recorded limited motion in both the ankle and knee, which was controversial with regard to current understanding that a reduction of the walking speed increases the range of joints' motion in order to maintain the rhythm of walking and achieve proper balance in motion. In BW, there was a lack of a clear peak plantar flexion in the ankle, but clear dorsiflexion during striking periods; meanwhile, similar results were found for the knee. To some extent, our results indicated that the heel-strike gait was missing, so it required a strong muscle to provide a cushion, such as the tibialis anterior in the shank; consequently, a peculiar pattern was found in the BW [19].

In terms of CRP, the ankle and knee of FW were always in the status of out-phase; whereas, BW was recorded partly in the in-phase. Although in-phase or out phase did not imply better or inferior coordination, FW usually represented better coordination, as well as a lower energy cost. In this viewpoint, BW was a type of gait with a high energy cost, and it was usually performed with uncertainty to some extent, which could be proved by the fluctuating curves in BW. Due to the different protocols, our results were not consistent with the those of Pieter's [5]. Generally, similar coordination strategies in FW-BW were found in children age 3-6, but variations existed between two walking types; hence, our hypothesis was partly approved.

Current literature [5] further shows that age has a moderate effect on the gait of school-aged children, such as the range of lower limbs movement, but finally concludes that the development of school-aged children has 
already completed and limited progress in the gait of multi-direction movement was gained. This finding was confirmed by Dietz [20] who demonstrated that the nerve control of schoolaged children can be easily switched between FW and BW by using EMG-analysis. In our cases, gender differences existed in each age group. Boys 3 to 4 years of age showed a limited range of ankle motion, while, at age 5 and 6, major differences were found in the knees. Girls performed at a higher PA-Knee than that of boys. These phenomena might be due to a heavier bodyweight in boys and taller body height in girls, which could shorten the range of ankle motion [8], but increase that of the knee.

Although the above results further indicate the gait mechanism and coordination of different exercise directions of 3-6 year old children, there are some limitations: (1) children chose their preferred walking speed during measurement; although the walking speed affected the amplitude of motion, in this study, normalization was made to diminish the influence of speed; (2) markers were set on tight clothing rather than skin, which would cause movement of the marker while walking; in order to overcome this defect, a $6 \mathrm{~Hz}$ cut off strategy was applied in the period of data processing; (3) broad categories of age were chosen in our study, and this would ignore details of development within one year of age; however, classification into a one year interval could give a view of children's development in coordination.

\section{CONCLUSIONS}

Overall, although achieving the BW was easy for preshcool todders (aged 3-6), but their coordination in lower-limb were still in developing and further fine turning; moreover, their clues in backwarding also tell the detail of develop in the 'Neuro-musculo-skeletal' system.

\section{REFERENCES}

1. Cioni, G., Duchini, F., Milianti, B. et al., Early Hum Dev, 1993, 35, 35, 193-205, https://doi. org/10.1016/0378-3782(93)90106-5.

2. Verbecque, E., Meyns, P., Desloovere, K. et al., Gait Posture, 2016, 44, 116-122, https://doi. org/10.1016/j.gaitpost.2015.11.016.

3. Slobounov, S.M., Newell, K.M., Hum Mov Sci, 1994, 13, 6, 861-75, https://doi. org/10.1016/0167-9457(94)90022-1.

4. Newell, K.M., Slobounova, B.S., Molenaar, P.C.M., Gait Posture, 1997, 6, 56-62, https:// doi.org/10.1016/S0966-6362(96)01103-4.

5. Meyns, P., Desloovere, K., Molenaers, G. et al., PLOSONE, 2013, 8, 4, e62747-e62747, https:// doi.org/10.1371/journal.pone.0062747.

6. Duysens, J., Murrer, L., Dietz, V., J Neurophysiol, 1996, 76, 301-310, https://doi.org/10.1152/ jn.1996.76.1.301.

7. Hallemans, A., D’Août, K., De, C.D. et al., Foot Ankle Int, 2003, 24, 5, 444-453, https://doi.or $\mathrm{g} / 10.1177 / 107110070302400513$.

8. Bosch, K., Gerss, J., Rosenbaum, D., Gait Posture, 2010, 32, 4, 564-71, https://doi. org/10.1016/j.gaitpost.2010.08.003.

9. Ledebt, A., Infant Behav Dev, 2000, 23, 79-89, $\quad$ https://doi.org/10.1016/S01636383(00)00027-8.

10. Fritz, N.E., Worstell, A.M., Kloos, A.D., Gait Posture, 2013, 37, 4, 593-597, https://doi. org/10.1016/j.gaitpost.2012.09.022.

11. Lee, M., Kim, J., Son, J., Kim, Y., Gait Posture, 2013, 38, 4, 674-678, https://doi. org/10.1016/j.gaitpost.2013.02.014.

12. Working Group Of China Obesity, Chinese Journal of Epidemiology, 2004, 25, 2, 97-102.

13. Clark, J.E., Phillips, S.J., Child Dev, 1993, 64, 4, 1143-1157, https://doi. org/10.2307/1131331. 
14. Miller, R.H., Baird, C.J.L., Emmerik, R.E.A.V. et al., J Biomech, 2010, 43, 13, 2554-2560, $\quad$ https://doi.org/10.1016/j. jbiomech.2010.05.014.

15. Rose, J., Wolff, D.R., Jones, V.K. et al., Dev Med Child Neurol, 2002, 44, 1, 58-63, https://doi. org/10.1111/j.1469-8749.2002.tb00260.x.

16. Clark, J.E., Phillips, S.J., Advances in Psychology, 1991, 81, 245-257, https://doi. org/10.1016/S0166-4115(08)60769-4.

17. Hu, M., Zhou, N., Xu, B. et al., Gait Posture, 2016, 50, 82-88, https://doi.org/10.1016/j. gaitpost.2016.08.025.

18. Hallemans, A., Ortibus, E., Meire, F. et al., Gait Posture, 2010, 32, 4, 547-51, https://doi. org/10.1016/j.gaitpost.2010.07.018.
19. Jansen, K., De, G.F., Massaad, F. et al., J Neurophysiol, 2012, 107, 12, 3385-3396, https://doi.org/10.1152/jn.01156.2011.

20. Dietz, V., Trends Neurosci, 2002, 25, 462-467, https://doi.org/10.1016/S01662236(02)02229-4.

(C) 2018 by the author(s). Published by INCDTP-ICPI, Bucharest, RO. This is an open access article distributed under the terms and conditions of the Creative Commons Attribution license (http://creativecommons.org/licenses/ by/4.0/). 